\title{
Ontogeny of ovarian follicle development in Booroola sheep fetuses that are homozygous carriers or non-carriers of the $\mathrm{Fec}^{\mathrm{B}}$ gene
}

\author{
P. Smith, R. Braw-Tal*, K. Corrigan, N. L. Hudson, \\ D. A. Heath and K. P. McNatty \\ Wallaceville Animal Research Centre, PO Box 40063, Upper Hutt, New Zealand
}

\begin{abstract}
The aims of this study were to examine the effects of the Booroola $\mathrm{Fec}^{\mathrm{B}}$ gene on ovarian development and reproductive hormones (FSH, LH and inhibin) at days 90, 100, 120 and 135 of gestation (term $=147$ days). The effects of litter size were eliminated by transferring equal numbers of homozygous $\mathrm{BB}$ and control $(++)$ embryos to recipient ewes. The ovary, but not the body, pituitary, adrenal, kidney or thymus, was heavier $(P<0.05)$ in $\mathrm{BB}$ compared with ++ fetuses at day 90 but not thereafter. In the ovary, gene-specific differences were observed in the total number of germ cells present at days $90(P<0.01)$ and $135(P<0.05)$ with the same tendency being noted at day $100(P<0.07)$; at all of these ages the mean numbers of germ cells in the $\mathrm{BB}$ genotype exceeded those in ++ animals. Gene-specific differences were observed in the numbers of oogonia and isolated oocytes at day 90 (i.e. $\mathrm{BB}>++$ ), in the number of primordial follicles at days $100(\mathrm{BB}>++)$ and 135 $(\mathrm{BB}>++)$, and also in the number of primary or secondary follicles $(++>\mathrm{BB})$ at day 135 . At each gestational age examined no differences were noted with respect to the plasma concentrations of FSH, LH or inhibin between the BB and ++ fetuses. However, the highest mean plasma concentrations of FSH and LH occurred at days 90 and 100 of gestation, which coincided with the first developing primary follicles. Collectively, the results from this and previous studies show that the different effects of the Fec ${ }^{\mathrm{B}}$ gene in germ cell development in early gestation continue throughout fetal development independently of litter size. Moreover, during the growth of the first primary and secondary follicles at days 100 and 120 , respectively, there are no differences in the plasma concentrations of FSH, $\mathrm{LH}$ and inhibin with respect to Booroola genotype.
\end{abstract}

\section{Introduction}

In Booroola sheep, there is evidence that the fecundity gene $\mathrm{Fec}^{\mathrm{B}}$ influences litter size, body mass and ovarian germ cell development during fetal life (Smith et al., 1993). At days 40 and 90 of gestation, it was demonstrated with embryo-transfer studies that the effects of the $\mathrm{Fec}^{\mathrm{B}}$ gene on ovarian germ cell development were independent of litter size. However, at later stages of gestation (i.e. days 95 and 135) the putative gene effects on follicle formation or follicular growth were compromised by differences in litter size. For example, at day 135 the studies of Smith et al. (1993) reported that the mean litter size was 2.4 in $\mathrm{Fec}^{\mathrm{B}}$ carriers, whereas for the controls it was 1.3; this difference in litter size was associated with the recovery of smaller and lighter fetuses from $\mathrm{Fec}^{\mathrm{B}}$ carriers compared with the controls. Thus, it remains uncertain whether the gene-specific differences in germ cell development in early-mid-gestation

*Present address: The Volcani Center, Institute of Animal Science, Agriculture Research Organisation, Bet-Dagan, PO Box 6, Israel. Received 2 June 1993. persist throughout late gestation. Notwithstanding the presence or absence of any litter size effects, no differences were noted between the genotypes with respect to the ovarian contents of inhibin or oestradiol or plasma concentrations of FSH, LH or inhibin.

The aims of the present studies were to examine in more detail the effects of the $\mathrm{Fec}^{\mathrm{B}}$ gene on ovarian development and reproductive hormones ( $\mathrm{FSH}, \mathrm{LH}$ and inhibin) in female fetuses during late gestation, namely on days 90, 100, 120 and 135 . The possible effects of litter size were eliminated by studying these characteristics in Booroola fetuses following the transfer of equal numbers of $\mathrm{BB}$ or ++ embryos to recipient Romney ewes.

\section{Materials and Methods}

The experimental procedures reported in this study were carried out in accordance with the 1987 Animal Protection (Codes of Ethical Conduct) Regulations of New Zealand after approval was granted by the Animal Ethics Committee of the Wallaceville Animal Research Centre. 


\section{Animals and treatments}

Female fetuses $(++$ or $\mathrm{BB})$ were recovered at days 90 $(n=28), 100(n=21), 120(n=16)$ and $135(n=24)$ following the transfer of 4-5-day-old embryos to Romney ewes. The BB fetuses were the result of matings between $B B$ Booroola Romney rams $(n=6)$ and superovulated BB Booroola Romney ewes $(n=11)$. The ++ fetuses were the result of matings between ++ Booroola Romney rams $(n=7)$ and superovulated ++ Booroola Romney ewes $(n=15)$. The BB and ++ ewes were superovulated using pregnant mares' serum gonadotrophin (PMSG; Folligon: Intervet, Lane Cove) and Ovagen (Immuno-chemical Products Ltd, Auckland), as described by Smith et al. (1993). The superovulated ewes were mated either individually or in pairs with a ram. Overall, seven different ++ and six different $B B$ rams were used. Four or five days after mating, $138++$ embryos and 147 BB embryos were recovered and transferred into 95 oestrous synchronized recipient Romney ewes (three embryos per ewe) using a laparoscopic technique (see Smith et al., 1993).

Fetuses were recovered after a barbiturate overdose (Euthatal: South Island Chemicals, Christchurch; about $20 \mathrm{ml}$ i.v. of a solution containing $500 \mathrm{mg} \mathrm{ml}^{-1}, \mathrm{w} / \mathrm{v}$ ) was given to their mothers. The fetal blood samples were collected by cardiac puncture, centrifuged at $4000 \mathrm{~g}$ for $20 \mathrm{~min}$ at $4^{\circ} \mathrm{C}$ and the plasma stored at $-15^{\circ} \mathrm{C}$ until assayed for hormones. After collection of blood samples from the female fetuses, the ovaries, adrenals, pituitary, thymus and kidneys were isolated and weighed. The right ovary from each fetus was then prepared for morphometric studies.

\section{Morphometric studies}

The right ovary from each fetus was fixed in Bouin's fixative, processed for histology and embedded in plastic (Technovit 7100, Kulzer). Subsequently, the ovaries were serially sectioned at $30 \mu \mathrm{m}$ for volume estimations and optical sectioning. Ovarian volume was estimated by the Cavalieri principle. The areas $(a)$ of every tenth section were estimated by point counting, and the ovarian volume calculated from the product of $(a \times h)$ where $h$ is the distance $(\mu \mathrm{m})$ between every tenth section.

The volume estimations and principles involving counting of germ cells by the nuclear disector method are outlined by Gunderson (1986) and Smith et al. (1993). In this study, a modification of the nuclear disector procedures called optical dissection, which uses $30 \mu \mathrm{m}$ rather than $4 \mu \mathrm{m}$ tissue sections, wase used. These modified procedures are outlined below. High numerical aperture oil immersion objectives (with limited focal depth), a modified Olympus BH microscope fitted with a linear depth gauge unit (Mitutoyo Corporation, Minato-ku, Tokyo), and a motorized stage modified for stereology (Bico Productions, Glostrup, Copenhagen) were used and optical sections were made through the depth of thick plastic sections. By focusing through a known distance (limited only by the section thickness) of the section and counting the new germ cell nucleii that come into focus, a series of consecutive disectors can effectively be taken, in which the optical section serves both as the reference and look-up section as the depth of the section is scanned. An unbiased counting frame placed over video images and the motorized stage were used to obtain random but systematic fields; the germ cell number $(n)$ was estimated by:

$$
n=\frac{\Sigma Q}{\Sigma A H} V_{\mathrm{o}}
$$

where $Q$ is the new germ cell nucleii counted in the frame, $A$ is the area of the counting frame $(\mu \mathrm{m}), H$ is the depth focused through the section $(\mu \mathrm{m})$, and $V_{\mathrm{o}}$ is the ovarian volume. The counts were performed by three different operators and a proportion of the ovaries was counted by at least two operators independently and both estimates were within $10 \%$. The coefficients of error due to the stereological sampling procedures were determined by the method of Pakkenberg and Gundersen (1988) and West and Gundersen (1990).

Germ cells were classified into oogonia (germ cells devoid of follicle cells with an intact nuclear membrane), oocytes (germ cells devoid of follicle cells and undergoing meiosis where the nuclear membrane was no longer intact), primordial follicles (germ cells completely surrounded by flattened follicle cells), primary follicles (oocytes completely surrounded by one layer of cells with one or more of the follicle cells being cuboidal in shape) and secondary follicles (oocytes surrounded by more than one concentric layer of cuboidal cells).

\section{Hormone assays}

The FSH and LH radioimmunoassays were identical to those described by McNatty et al. (1989). The ovine (o) FSH for iodination was NIAMDD-oFSH-I- 1 , the oFSH reference preparation was NIAMDD-oFSH-RPI (biopotency $75 \times$ NIH-FSHS1) and the oFSH antiserum was NIAMDD-anti-oFSH- 1 (AFPC5288113). The LH iodination standard was NIDDK-oLH-I-3 (AFP-9598B); the LH antiserum was raised at the Wallaceville Animal Research Centre and is described by McNatty and Henderson (1987). The oLH reference preparation was NIAMDD-oLH-23 (biopotency $2.3 \times \mathrm{NIH}-\mathrm{LH}-\mathrm{SI}$ ). For both assays the volume of plasma assayed in duplicate was $0.1 \mathrm{ml}$. The internal standards and standard curve samples were prepared in FSH- and LH-free hypophysectomized ewe plasma. In addition, for both assays the overall intra- and interassay coefficients of variation (CV) for the internal standards that were included with every standard curve estimation were $<10 \%$. The minimum detectable concentration of $\mathrm{FSH}$ or $\mathrm{LH}$ was $0.2 \mathrm{ng} \mathrm{ml}^{-1}$.

The inhibin radioimmunoassay kit was purchased from DM Robertson, Monash University, Melbourne, and consisted of a highly purified $31 \mathrm{kDa}$ bovine inhibin for iodination and a rabbit anti-31-kDa-inhibin preparation (No. 1989). The specificity of this assay, including its validation for sheep plasma, are described by Robertson et al. (1989), Findlay et al. (1990) and McNatty et al. (1992). The reference standard was a pool of charcoal-treated ovine follicular fluid (batch 2). Relative to the WHO (86/690) inhibin standard (National Institute of Biological Standards and Control, Potters Bar) the batch 2 reference standard had an inhibin activity of $490300 \mathrm{iu} \mathrm{ml}^{-1}$. The assay buffer was $0.1 \mathrm{~mol}$ phosphate buffer $\mathrm{I}^{-1}$ with $0.15 \mathrm{~mol}$ sodium chloride $\mathrm{l}^{-1}$ and $5 \%(\mathrm{w} / \mathrm{v}) \mathrm{BSA}, \mathrm{pH}$ 7.4. Standards or unknowns were diluted in ovariectomized ovine plasma 
Table 1. Effect of embryo transfer on litter size (mean \pm SEM) with respect to age of gestation and genotype

\begin{tabular}{|c|c|c|c|c|c|c|}
\hline \multirow{2}{*}{$\begin{array}{l}\text { Age of } \\
\text { gestation } \\
\text { (days) }\end{array}$} & \multirow[b]{2}{*}{ Genotype } & \multicolumn{3}{|c|}{ Number of recipient ewes with a litter size of } & \multirow[b]{2}{*}{ Mean litter size $e^{a}$} & \multirow{2}{*}{$\begin{array}{c}\text { Number of female } \\
\text { embryos }\end{array}$} \\
\hline & & 1 & 2 & 3 & & \\
\hline \multirow[t]{2}{*}{90} & ++ & 1 & 3 & 5 & $2.4 \pm 0.2$ & 14 \\
\hline & $\mathrm{BB}$ & - & 3 & 6 & $2.7 \pm 0.2$ & 14 \\
\hline \multirow[t]{2}{*}{100} & ++ & 2 & 4 & 3 & $2.1 \pm 0.3$ & 10 \\
\hline & $\mathrm{BB}$ & - & 7 & 1 & $2.1 \pm 0.1$ & 11 \\
\hline \multirow[t]{2}{*}{120} & ++ & - & 3 & 1 & $2.3 \pm 0.3$ & 6 \\
\hline & $\mathrm{BB}$ & 3 & 3 & 2 & $1.9 \pm 0.3$ & 10 \\
\hline \multirow[t]{2}{*}{135} & ++ & 1 & 8 & - & $1.9 \pm 0.1$ & 11 \\
\hline & BB & 1 & 7 & 2 & $2.1 \pm 0.2$ & 13 \\
\hline
\end{tabular}

${ }^{2}$ Litter sizes only relate to those that include at least one female embryo in the litter.

(previously determined to be free of immunoreactive inhibinlike activity) to a volume of $100 \mu$.

The sensitivity of the assay (i.e. at $10 \%$ displacement of the tracer) was $<0.5$ iu per tube both in the presence or absence of ovariectomized ovine plasma. The mean intra- and interassay $\mathrm{CV}$ values were both $<16 \%$.

\section{Statistical analyses}

In most instances data from individual fetuses were log transformed and subjected to analysis of variance to test for differences between genotypes. These data are presented as geometric means (and 95\% confidence intervals). In some instances, such as in comparisons of litter size between genotypes, the Mann-Whitney test was used.

\section{Results}

Effect of embryo transfer on litter size with respect to gestational age and Booroola genotype

Female embryos were recovered from 66 of the 95 recipient ewes. Data for these 66 ewes are summarized (Table 1). At each gestational age there was no effect of genotype on mean litter size.

\section{Effect of Booroola genotype on body mass and organ masses}

With the exception of ovarian mass at day 90 (BB $>++$; $P<0.05\rangle$ no effects of genotype were noted on body mass or ovarian, pituitary or adrenal mass at any gestational age (Table 2). Moreover, no effects of genotype were noted on the masses of the thymus or kidney (data not shown).

\section{Effect of Booroola genotype on ovarian characteristics}

The effect of Booroola genotype on ovarian volume and number of germ cells is summarized (Table 3). At days 90-135 of gestation, almost all the germ cells were located in the ovarian cortex. The medullary region of the ovary was characterized by connective tissue, blood vessels and a prominent rete system. At days 90 and 100 , but not at days 120 or 135, of gestation, the mean ovarian volumes in the BB genotype were significantly greater than in the ++ genotype. At days 90 and 135, the total number of germ cells was larger in $\mathrm{BB}$ compared with the ++ genotype (day $90, P<0.01$; day $135, P<0.05)$; the same tendency was noted at day 100 (BB $>++, P<0.07)$, but not at day 120 .

The mean numbers of oogonia, isolated oocytes, primordial follicles and primary and secondary follicles with respect to day of gestation and Booroola genotype are summarized (Fig. 1). At day 90 , most (i.e. 70-90\%) germ cells were present as either oogonia or isolated oocytes. There was also an appreciable number (i.e. $5-10 \%$ ) of primordial follicles, but no primary or secondary follicles were present. At day 100, most (i.e. $75-90 \%$ ) germ cells were present either as isolated oocytes or enclosed in primordial follicles and most of the remainder $(<10 \%)$ was present as oogonia. Although there was considerable variability between fetuses, there was also a small proportion (i.e. $0.2-0.7 \%$ ) of the total germ cell population present as primary follicles, but follicles beyond this stage of growth were not seen. At day 120, most of the germ cells (i.e. $\geq 90 \%$ ) were present as primordial follicles or isolated oocytes (with the number of oogonia declining to low levels (i.e. $<2 \%$ of the total number of germ cells). At this time a small proportion of both primary follicles and secondary follicles was noted, with the most advanced of the growing follicles containing three concentric layers of granulosa cells. By day 135 , most germ cells (i.e. $\geq 75 \%$ ) were present as primordial follicles with up to $3 \%$ in growing follicles (i.e. up to early antral structures); the remainder were present as oocytes.

At day 90, fetuses of the BB genotype contained significantly more oogonia $(P<0.001)$ and isolated oocytes $(P<0.05)$ than did the ++ animals. At day 100, the $\mathrm{BB}$ animals contained significantly more primordial follicles $(P<0.001)$ compared with the ++ genotype. At day 135 , the BB genotype contained more primordial follicles $(P<0.05)$ but fewer primary and secondary follicles $(P<0.05)$ than did the ++ animals. 
Table 2. Body mass and organ masses in female fetuses with respect to Booroola genotype (BB or ++$)$ and age of gestation

\begin{tabular}{|c|c|c|c|c|c|}
\hline $\begin{array}{l}\text { Age of } \\
\text { gestation } \\
\text { (days) }\end{array}$ & $\begin{array}{c}\text { Genotype } \\
(n)\end{array}$ & $\begin{array}{c}\text { Body mass } \\
\text { (g) }\end{array}$ & $\begin{array}{l}\text { Ovary mass } \\
(\mathrm{mg})\end{array}$ & $\begin{array}{l}\text { Pituitary mass } \\
\text { (mg) }\end{array}$ & $\begin{array}{l}\text { Adrenal mass } \\
(\mathrm{mg})\end{array}$ \\
\hline \multirow[t]{4}{*}{90} & ++ & 480 & 14 & 31 & 57 \\
\hline & (14) & $(445,517)$ & $(13,16)$ & $(26,37)$ & $(50,64)$ \\
\hline & $\mathrm{BB}$ & 444 & $18^{*}$ & 30 & 57 \\
\hline & (14) & $(408,484)$ & $(16,21)$ & $(26,34)$ & $(49,65)$ \\
\hline \multirow[t]{4}{*}{100} & ++ & 850 & 14 & 42 & 69 \\
\hline & (10) & $(728,993)$ & $(11,17)$ & $(34,49)$ & $(62,75)$ \\
\hline & $\mathrm{BB}$ & 722 & 16 & 42 & 63 \\
\hline & (1I) & $(621,840)$ & $(15,18)$ & $(33,51)$ & $(52,75)$ \\
\hline \multirow[t]{4}{*}{120} & ++ & 1907 & 22 & 63 & 116 \\
\hline & (6) & $(1687,2156)$ & $(17,26)$ & $(47,79)$ & $(103,129)$ \\
\hline & BB & 1588 & 19 & 61 & 116 \\
\hline & (10) & $(1332,1893)$ & $(16,22)$ & $(48,72)$ & $(106,126)$ \\
\hline \multirow[t]{4}{*}{135} & ++ & 3106 & 26 & 77 & 159 \\
\hline & (11) & $(2669,3615)$ & $(20,33)$ & $(65,90)$ & $(134,185)$ \\
\hline & $\mathrm{BB}$ & 2995 & 27 & 83 & 156 \\
\hline & (13) & $(2783,3222)$ & $(22,31)$ & $(74,92)$ & $(142,170)$ \\
\hline
\end{tabular}

Values are geometric means (and $95 \%$ confidence limits). ${ }^{*} P<0.05$ compared to ++ genotype at 90 days gestation. $n$ : number of fetuses. For the ovary and adrenal a mean mass from each fetus was obtained before the overall mean for each genotype at each gestational age was calculated.

Table 3. Ovarian volume and number of germ cells in female fetuses with respect to Booroola genotype $(\mathrm{BB}$ or ++$)$ and age of gestation

\begin{tabular}{|c|c|c|c|c|}
\hline $\begin{array}{l}\text { Age of } \\
\text { gestation } \\
\text { (days) }\end{array}$ & Genotype & $\begin{array}{l}\text { Ovarian volume } \\
\qquad\left(\mathrm{mm}^{3}\right)\end{array}$ & $\begin{array}{l}\text { Number of germ } \\
\text { cells } \times 10^{3}\end{array}$ & $\begin{array}{l}\text { Number of } \\
\text { fetuses }\end{array}$ \\
\hline \multirow[t]{2}{*}{90} & ++ & $\begin{array}{c}12.2 \\
(10.8,13.7)\end{array}$ & $\begin{array}{c}296 \\
(227,385)\end{array}$ & 14 \\
\hline & $\mathrm{BB}$ & $\begin{array}{c}15.5^{*} \\
(13.2,18.1)\end{array}$ & $\begin{array}{c}526^{* *} \\
(417,662)\end{array}$ & 14 \\
\hline \multirow[t]{2}{*}{100} & ++ & $\begin{array}{c}15.4 \\
(13.0,18.1)\end{array}$ & $\begin{array}{c}203 \\
(143,288)\end{array}$ & 10 \\
\hline & BB & $\begin{array}{c}21.3^{* *} \\
(19.0,23.9)\end{array}$ & $\begin{array}{c}287^{+} \\
(223,368)\end{array}$ & 11 \\
\hline \multirow[t]{2}{*}{120} & ++ & $\begin{array}{c}22.0 \\
(18.4,26.3)\end{array}$ & $\begin{array}{c}219 \\
(164,293)\end{array}$ & 6 \\
\hline & $\mathrm{BB}$ & $\begin{array}{c}20.8 \\
(18.8,22.1)\end{array}$ & $\begin{array}{c}190 \\
(135,267)\end{array}$ & 10 \\
\hline \multirow[t]{2}{*}{135} & ++ & $\begin{array}{c}26.0 \\
(20.5,32.8)\end{array}$ & $\begin{array}{c}87 \\
(67,111)\end{array}$ & 11 \\
\hline & $\mathrm{BB}$ & $\begin{array}{c}22.8 \\
(18.6,28.0)\end{array}$ & $\begin{array}{l}133^{*} \\
(93,191)\end{array}$ & 13 \\
\hline
\end{tabular}

Values are geometric means (and 95\% confidence limits)

${ }^{*} P<0.05,{ }^{* *} P<0.01,{ }^{+} P<0.07$ compared with the ++ genotype at the same age of gestation.

Effect of Booroola genotype on the plasma concentrations of FSH, LH and inhibin

No differences between the genotypes were noted for any hormone at any gestational age. The plasma concentrations for each hormone at each gestational age were pooled and the data are summarized (Table 4). For FSH and LH, the overall mean concentrations were highest at days 90 and 100, lowest at day 135 , and intermediate at day 120 . For inhibin values, the mean concentrations in both genotypes remained essentially unchanged at days 90 and 100, but increased to peak values at day 120 and thereafter declined to low values at day 135 . 


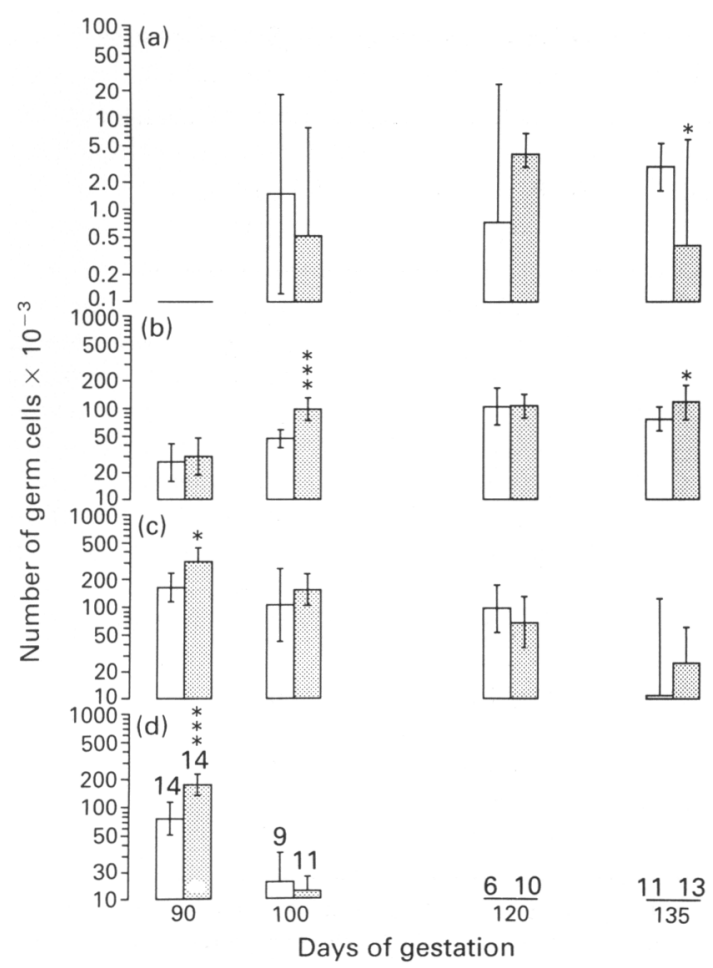

Fig. 1. Number of (a) primary and secondary follicles, (b) primordial follicles, (c) oocytes or (d) oogonia in $++(\square$ ) and BB (图) female Booroola sheep fetuses at different days of gestation. The histograms refer to geometric means and vertical bars to the $95 \%$ confidence limits. The numbers above the histograms refer to the number of fetuses. ${ }^{*} P<0.05,{ }^{* *} P<0.001$.

\section{Discussion}

The present results confirm and extend those of a previous study (Smith et al., 1993) that the Booroola $\mathrm{Fec}^{\mathrm{B}}$ gene affects ovarian development independently of litter size. At day 90 the ovary but not body mass or mass of pituitary, adrenal, thymus and kidney was greater in the BB than in the ++ genotype. Likewise at day 90 , the ovarian volume and total number of germ cells were higher in the BB than in the ++ genotype. The effects of the $\mathrm{Fec}^{\mathrm{B}}$ gene on ovarian development extended to day 100 with respect to ovarian volume and number of germ cells, but at later stages of gestation no gene effects were noted on either ovarian mass or volume. However, at the level of germ cell development, this study has shown that gene differences are observed between the numbers of oogonia and isolated oocytes (i.e. $\mathrm{BB}>++$ ) at day 90 , between the numbers of primordial follicles at day 100 (i.e. $B B>++$ ) and between the number of primordial follicles $(B B>++)$ and primary and secondary follicles $(++>B B)$ at day 135 . When these data on Booroola fetuses are considered together with those from an earlier study examining germ cell development from day 40 of gestation (Smith et al., 1993), it seems that independent of litter size, the $\mathrm{Fec}^{\mathrm{B}}$ gene affects body mass, the mesonephros and ovarian germ cell development in early gestation (for example, day 40). By day 55, there are no longer genotype differences in the mass of the mesonephros and thereafter this organ disappears as a distinct entity. From day 55 to day 135 of gestation, there are also no differences in body mass. Thus, from day 55 to day 135, the principal effects of the $\mathrm{Fec}^{\mathrm{B}}$ gene appear to be localized within the ovary on germ cell and follicle development. For example, the ++ genotype has more oogonia at day 40 , more germ cells entering meiosis at day 55 and more primordial follicles developing at day 75 and a greater loss of germ cells by atresia at day 90 (Smith et al., 1993). In the study reported here, the presence of more oogonia and more oocytes in $\mathrm{BB}$ than in the ++ genotype at day 90, more primordial follicles in BB than in the ++ genotype at day 100 and day 135 , and fewer primary and secondary follicles at day 135 is consistent with the view that germ cell development in the $\mathrm{BB}$ genotype is retarded relative to that in the ++ genotype (Smith et al., 1993). The failure to observe differences between the genotypes at day 120 might be because insufficient ++ female fetuses were recovered for a rigorous comparison. Notwithstanding this uncertainty, it seems likely that the apparent differences caused by $\mathrm{Fec}^{\mathrm{B}}$ in numbers of primordial follicles, primary and growing follicles previously reported at day 135 of gestation were not entirely due to litter size (Smith et al., 1993), since similar results were obtained in the present study where litter size in both genotypes were the same.

Table 4. The plasma concentrations of FSH (ng ml ${ }^{-1}$ ), $\mathrm{LH}\left(\mathrm{ng} \mathrm{ml}^{-1}\right)$ and inhibin (iu ml ${ }^{-1}$ ) in sheep fetuses with respect to gestational age

\begin{tabular}{|c|c|c|c|c|}
\hline \multirow[b]{2}{*}{ Hormone } & \multicolumn{4}{|c|}{ Days of gestation } \\
\hline & 90 & 100 & 120 & 135 \\
\hline $\begin{array}{l}\text { FSH } \\
(n)\end{array}$ & $\begin{array}{c}2.2(1.7,2.8)^{a, b} \\
(28)\end{array}$ & $\begin{array}{c}2.5(2.1,3.0)^{a} \\
(20)\end{array}$ & $\begin{array}{c}1.5(1.1,1.9)^{\mathrm{b}, \mathrm{c}} \\
(16)\end{array}$ & $\begin{array}{c}0.8(0.6,1.1)^{c} \\
(24)\end{array}$ \\
\hline $\mathrm{LH}$ & $2.1(1.5,2.7)^{a, b}$ & $2.3(1.4,3.5)^{\mathrm{a}}$ & $0.9(0.4,1.6)^{\mathrm{a}, \mathrm{c}}$ & $0.6(0.4,0.8)^{\mathrm{c}}$ \\
\hline$(n)$ & (25) & (17) & (12) & (19) \\
\hline $\begin{array}{l}\text { Inhibin } \\
(n)\end{array}$ & $\begin{array}{c}20(16,23)^{a} \\
(28)\end{array}$ & $\begin{array}{c}19(15,23)^{\mathrm{a}} \\
(20)\end{array}$ & $\begin{array}{c}34(24,48)^{b} \\
(16)\end{array}$ & $\begin{array}{c}16(12,22)^{a} \\
(24)\end{array}$ \\
\hline
\end{tabular}

Values are geometric means (and $95 \%$ confidence limits). ${ }^{a}$ versus ${ }^{b}, P<0.05 ;{ }^{b}$ versus ${ }^{c}, P<0.05 ;^{a}$ versus ${ }^{c}, P<0.01$ (ANOVA). $n$, number of animals from which blood samples were obtained. 
The different effects of the $\mathrm{Fec}^{\mathrm{B}}$ gene in germ cell development in the last trimester of pregnancy appear to continue with respect to follicular development in the prepubertal and adult Booroola ewe and also in long-term hypophysectomized Booroola ewes. For example, differences between the Booroola genotypes occur with respect to the diameters at which follicles mature (++> BB) (McNatty et al., 1991); these differences appear to be due to some aspect of granulosa cell development. In BB ewes, granulosa cells reach a similar stage of differentiation to those in ++ ewes but with one less cell division (McNatty and Henderson, 1987). Since follicles of >0.1$0.5 \mathrm{~mm}$ diameter in BB ewes have reached a similar stage of maturation to those of $>0.5-1.0 \mathrm{~mm}$ diameter in ++ ewes (McNatty et al., 1986), the gene-specific differences in granulosa cells have arisen at least $4-5$ cell divisions before follicular rupture. Whether a common factor is responsible for the difference caused by $\mathrm{Fec}^{\mathrm{B}}$ in germ cell maturation in fetal life and in developing follicles in the prepubertal and adult animals is unknown. Perhaps the key to resolving this issue is the mesonephros, which is significantly heavier in the ++ than in the $\mathrm{BB}$ genotype in early fetal life. The mesonephros is considered to be the source of the granulosa cells in the developing ovary. It is reasonable to speculate that the mesonephros and thus the differentiation of the mesonephrosderived granulosa cells in early gestation might contribute to at least some of the differences observed in germ cell development, follicle formation and subsequently follicle growth observed in this and in other studies (for review see Montgomery et al., 1992).

The study reported here establishes that before parturition, there are no gene-specific differences in the plasma concentrations of FSH or LH during the first stages of follicular growth. However, for both genotypes the highest mean concentrations of FSH and $\mathrm{LH}$ at days 90 and 100 of gestation coincided with the first growing (i.e. primary) follicles. It would be of interest to establish whether these high concentrations of gonadotrophins are important in initiating the onset of follicular growth. No gene-specific differences in plasma inhibin were observed at days 90,100 or 135 , when there were differences in ovarian germ cell development; these results confirm those of Smith et al. (1993). Despite differences in germ cell or follicle development between the Booroola genotypes in the last trimester, the lack of any differences in plasma inhibin are at least partly due to the fact that the ovary is not a major source of inhibin between days 90 and 135, as no mRNA activity for $\alpha$ or $\beta_{\mathrm{A}}$ inhibin could be detected at this time (R. Braw-Tal and D. Tisdall, unpublished).

The results from this and our earlier study (Smith et al., 1993) establish for sheep that although the first primordial follicles form at about day 75 , the first growing (i.e. primary) follicles are not observed until day 100 and that the first large preantral or early antral follicles develop at about day 135, 12 days before birth. In the sheep fetus the time taken for an early antral follicle to grow from a primary structure is therefore less than 45 days. This is substantially shorter than the times calculated for preantral follicular growth in adult sheep (Turnbull et al., 1977; Cahill, 1979).

In summary, these studies show that the $\mathrm{Fec}^{\mathrm{B}}$ gene specifically affects ovarian mass at day 90 and ovarian volume at days
90 and 100 of gestation without effecting the masses of other important endocrine organs such as the adrenal or pituitary glands. Moreover, during late gestation the major effect of the $\mathrm{Fec}^{\mathrm{B}}$ gene appears to be on ovarian germ cell and follicle development.

The authors thank G. Davis and K. Isaacs of the Invermay Agricultural Research Centre for the provision of the animals and details of their reproductive history. They acknowledge the assistance of G. Shackell of the Invermay Agricultural Research Centre for his major contribution to the embryo transfer experiments. Special thanks to $D$. Jensen and R. Bailey for assistance with oestrous synchronization and superovulation of the sheep and with embryo transfer. The authors acknowledge the work of $L$. Still for preparation and processing of tissues for histological studies, L. Berry and L. Shaw for the gonadotrophin assays, and the National Hormone and Pituitary Program and the NIADDK for the ovine radioimmunoassay reagents.

\section{References}

Cahill LP (1979) Studies of Folliculogenesis in the Sheep. PhD Thesis, University of Paris VI

Findlay JK, Clarke II and Robertson DM (1990) Inhibin concentrations in ovarian and jugular venous plasma and the relationship of inhibin with follicle stimulating hormone and luteinizing hormone during the ovine estrous cycle Endocrinology 126 528-535

Gundersen HJG (1986) Stereology of arbitrary particles: A review of unbiased number and size estimators and the presentation of some new ones Journal of Microscopy 143 3-45

McNatty KP and Henderson KM (1987) Gonadotrophins, fecundity genes and ovarian follicular function Joumal of Steroid Biochemistry 27 365-373

McNatty KP, O'Keeffe LE, McDiarmid J, Heath DA and Lun S (1986) Adenosine cyclic $3^{\prime}, 5^{\prime}$-monophosphate and steroid production by small ovarian follicles from Booroola ewes with and without a fecundity gene Journal of Reproduction and Fertility 76 471-480

McNatty KP, Hudson NL, Collins F, Fisher M, Heath DA and Henderson KM (1989) Effects of oestradiol-17 $\beta$, progesterone or bovine follicular fluid on the plasma concentrations of FSH and LH in ovariectomized Booroola ewes which were homozygous carriers or non-carriers of a fecundity gene Journal of Reproduction and Fertility 87 573-585

McNatty KP, Henderson KM, Fleming JS, Clarke IJ, Bindon BM, O'Shea J, Hillard MA and Findlay JK (1991) The physiology of the Booroola ewe. In Major Genes for Reproduction in Sheep Pp 105-125 Eds JM Elsen, L Bodin and J Thimonier. INRA, Toulouse

McNatty KP, Heath DA, Hudson NL, Ball K and Condell L (1992) Immunoreactive inhibin concentrations in ovarian and peripheral venous plasma and follicular fluid of Booroola ewes which were homozygous carriers or non-carriers of the Fec ${ }^{\mathrm{B}}$ gene Journal of Reproduction and Fertility 95 489-502

Montgomery GW, McNatty KP and Davis GH (1992).Physiology and molecular genetics of mutations that increase ovulation rate in sheep Endocrine Reviews 13 309-328

Pakkenberg B and Gundersen HIG (1988) Total number of neurons and glial cells in human brain nuclei estimated by the dissector and the fractionator Journal of Microscopy 150 I-20

Robertson DM, Giacometti M, Foulds LM, Lahnstein J, Goss NH, Hearn MTW and de Kretser DM (1989) Isolation of inhibin $\alpha$-subunit precursor proteins from bovine follicular fluid Endocrinology 125 2141-2149

Smith P, O W-S, Hudson NL, Shaw L, Heath DA, Condell L, Phillips DJ and McNatty KP (1993) Effects of the Booroola gene $\left(\mathrm{Fec}^{\mathrm{B}}\right.$ ) on body weight, ovarian development and hormone concentrations during fetal life Journal of Reproduction and Fertility 98 41-54

Turnbull KE, Braden AWH and Mattner PE (1977) The pattern of follicular growth and atresia in the ovine ovary Australian Journal of Biological Sciences 30 229-241

West MJ and Gundersen HJG (1990) Unbiased stereological estimation of the number of neurons in the human hippocampus Journal of Comparative Neurology 296 1-22 